reported that these guidelines were being updated. ${ }^{3}$ We hoped that the revised guidelines would address two of the problems that we had highlighted in our report-namely, unfairness in accreditation and general practitioners being required to attend basic courses. Unfortunately, neither of these problems is likely to be resolved by the revised guidelines, which are virtually unchanged except for a $U$ turn on the status of the MRCGP and DCH examinations. These qualifications are now thought to be evidence of competence in child health surveillance as an alternative to either three or more years' experience or attendance at an approved course. We do not think that family health services authorities are any more likely to follow these guidelines than they did the original ones.

Our survey showed that a greater percentage $(71 \%)$ of family health services authorities recog nised an approved training course than recognised three or more years' experience $(56 \%) .^{1}$ As a result many experienced principals were advised to attend courses on basic child surveillance. The suggested content of these courses in the revised guidelines is almost exactly the same as that in the original ones, including undergraduate and trainee material which is not appropriate for established principals in general practice. A danger of the present and proposed system is that general practitioners who are not accepted on to child surveillance lists have no incentive to provide a full service for children. On the other hand, there is also the danger that a basic course of 10 sessions will be considered to be adequate education in child surveillance for the whole of a principal's career.

We believe that every practising general practitioner should be encouraged to provide a full service to the children on his or her list. It would surely make sense to drop the "once and for all" hurdle of accreditation and instead set up a system of continuing education and audit for all those who wish to provide child health surveillance. Such a system would be more likely to ensure that high standards of care were maintained in general practice paediatrics.

ALISON EVANS

Department of General Practice,

Leeds University,

Leeds

Claremont Surgery,

Scarborough YO11 IXE

NEAL MASKREY

Meltham Road Surgery

PHILIP NOLAN

Huddersfield HDI 3 UP

1 Evans AJ, Maskrey N, Nolan P. Admission to child health surveillance lists: the views of FHSA general managers and general practitioners. BMF 1991;303:229.

2 Royal College of General Practitioners and British Paediatric Association. Guidelines for the training and accreditation of general practitioners in child health surveillance. London: RCGP, BPA, 1989.

3 Waine C. Child health surveillance lists. BMF 1991;303:202.

4 British Paediatric Association, General Medical Services Committee, Royal College of General Practitioners with the support of the Joint Committee on Postgraduate Training for General Practice. Training and accreditation of general practitioners in child health surveillance. London: BPA, GMSC, practitioners in

\section{Medical negligence}

SIR, - In his editorial Richard Smith calls for a no fault system in cases of medical negligence and criticises voluntary arbitration as proposed by the Department of Health. ' Additionally, he calls for a strategy to reduce medical accidents. These are both important issues but are not necessarily related or comparable in importance.

The Department of Health's proposals could help greatly in two ways. The panel of arbitrators would be sufficiently small for the experts to be able to meet quickly. The process would therefore be greatly speeded up so that justice would be more prompt. Also, the present system is so costly that many cannot afford even to start a claim unless they are eligible for legal aid. So these are considerable advances.

For those who are not injured by negligence the issue is to distinguish a medical accident, which implies an avoidable action, from unavoidable complications. The no fault concept would encounter this problem, and what is proposed is really an insurance system. And why only medical accidents and not others-for instance, road accidents - too? If no fault included negligence it would (not might, as Smith says in referring to arbitration) reduce the deterrent effect of litigation

In order to reduce medical accidents I agree that we have a good lead from the Harvard study of hospital records in the United States, which has been effective. ${ }^{2}$ We too need to audit the incidence of adverse events, especially in hospital practice. As with each of the major audits carried out in this country we would learn a great deal and, more importantly, reduce the problem. A proposal to carry out such an audit is being prepared at present.

The government's proposals are a positive step forward. If they were accompanied by an audit of medical accidents considerable progress would be possible in dealing with the basis of the problem. The subtitle of Smith's editorial could then be transposed to read "Forget no fault and go for arbitration and audit."

MICHAEL ROSEN

Department of Anaesthetics,

University Hospital of Wales,

Cardiff CF4 4XW

1 Smith R. Fiddling with medical negligence. BMF 1992;304 198-9. (25 January.)

2 Harvard Medical Practice Study. Patients, doctors, and lawyers. medical injury, malpractice litigation, and patient compensation in New York. Boston: Harvard Medical Practice Study, 1990.

\section{Patients' views of the patient's charter}

SIR, - Much is said about the patient's charter, which is portrayed by politicians as defining the inalienable rights of patients. But how and why did the charter emerge in this form, when for the most part it sets out so called rights that have been normal practice in health care for many years? Is the government being overly paternalistic or does the charter indeed reflect what patients find important in the health service today?

In the third week of November last year we interviewed 25 consecutive patients in the waiting rooms of each of eight general practices in south London. Our aim was to determine $(a)$ whether patients had heard of the patient's charter; $(b)$ how important they thought the rights were; and (c) whether they thought that each right was being fulfilled. The responses to the second and third questions were scored on a scale of 0-4. Finally, patients were asked if they would change the way that they used the NHS in view of their new rights. We had to paraphrase each of the 10 rights in the charter as we considered the wording to be too complex for easy digestion in a questionnaire.

Of 200 questionnaires returned, 167 had been fully completed and were included in our study ( 82 from men, 85 from women; mean age 40 ). Given that every household in Britain should have received a summary copy of the patient's charte by mid-November last year, we found that 91 patients were still ignorant of its existence at the time of our survey.

The table shows the degree of importance attached to each right and the degree to which the patients thought that each right was being fulfilled, expressed as the sum of the scores as a percentage of the maximum possible score of 668. Notably the degree to which each right was fulfilled was, without exception, lower than the degree of importance. The patients gave highest priority
Importance of each right to patients and degree to which patients thought each right was being fulfilled

\begin{tabular}{lcc}
\hline Right & $\begin{array}{c}\text { \% Importance* } \\
\text { (total score) }\end{array}$ & $\begin{array}{c}\text { \% Fulfilled } \\
\text { (total score) }\end{array}$ \\
\hline $\begin{array}{l}\text { To receive free health care } \\
\text { To receive emergency health } \\
\text { care }\end{array}$ & $97(648)$ & $82(547)$ \\
$\begin{array}{l}\text { To register with general } \\
\text { practitioner }\end{array}$ & $97(648)$ & $77(514)$ \\
$\begin{array}{l}\text { To be referred to specialist } \\
\text { To have treatment explained }\end{array}$ & $95(635)$ & $93(620)$ \\
$\begin{array}{l}\text { Guaranteed maximum 2 year } \\
\text { waiting list }\end{array}$ & $93(621)$ & $70(468)$ \\
$\begin{array}{l}\text { Investigation of complaints } \\
\text { Information on local health } \\
\text { services }\end{array}$ & $93(621)$ & $65(434)$ \\
$\begin{array}{l}\text { Non-participation in medical } \\
\text { education }\end{array}$ & $86(508)$ & $51(408)$ \\
Access to medical records & $80(534)$ & $56(374)$ \\
\end{tabular}

$\star$ Total score as percentage of maximum possible score (668)

to receiving free health care and emergency treatment. Of least importance were the non-clinical aspects of health care, such as access to medical records, non-participation in medical training, and information on local health care services and waiting times. The less important rights were perceived to be less fulfilled than those traditionally considered to be the basis of the NHS. Perhaps the neglected aspects of the health service merit future attention in these competitive times.

Will the government achieve the charter's standards by April, as promised, or will increased accessibility to redress lead to a torrent of complaints? Either the government has given us a stick with which to beat it or this represents a commitment to realistic change. Change, however, requires resources directed at the problems, and that may be the sticking point, regardless of all good intentions.

\section{MARTIN LEES LISA HALL ANDREW SHAW SARA GIL RIVAS CLAIRE MCCREADY PAUL EASTON JOHN LIM}

United Medical and Dental Schools

of Guy's and St Thomas's Hospitals, London SE1 7EH

\section{Doctors and Desert Storm}

SIR,-Judging by his comments about Desert Storm, the war in Iraq, David Widgery is a caring doctor. ${ }^{1} \mathrm{He}$ is probably distressed when he thinks about the millions of Chinese killed by the old warlords, the occupying Japanese, and the communists; images of the millions of Russians murdered by Stalin and by the Nazi death squads would trouble him, as would the memory of his compatriots wiped out by the Luftwaffe and the Germans destroyed by Bomber Command. He may shed a tear for the six million victims of the Holocaust, though, in Stalin's view, such a figure is not so much a tragedy as a statistic.

Widgery and similar propagandists never offer a better line of action that leaders of the Western democracies might have taken. How would he have dealt with Nazi Germany? Even Lord Russell thought that the Allies fought a just and righteous war between 1939 and 1945 . The United Nations having decided that Saddam Hussein should be removed from Kuwait, how would Widgery have achieved this end? Would he have tried the Chamberlain method? Churchill pointed out that the two main tasks of any government are to prevent war and to be prepared for it if it comes. Widgery has grasped the first point but not the second. A third world war was prevented not by the noises of International Physicians for the Prevention of Nuclear War but by the noise of the engines of American B52 aircraft on constant patrol in European skies. Widgery should realise 